\title{
Classroom Environment in Public Schools: Towards a more Reflective Teaching
}

El ambiente del aula en escuelas públicas:

hacia una enseñanza más reflexiva

O Ambiente de Sala de Aula em Escolas Públicas: Voltada a um Ensino mais Refletivo

Josefina Quintero-Corzo* iD orcid.org/0000-0002-9451-113x

Gloria Esperanza Infante-Castaño** iD orcid.org/0000-0002-3749-1611

Yeimy Paola Valencia-Roncancio*** iD orcid.org/0000-0002-4406-8045

Para citar este artículo: Quintero-Corzo, J., Infante-Castaño, G. y Valencia-Roncancio, Y. (2O21). Classroom Environment in Public Schools: Towards a more Reflective Teaching. Revista Colombiana de Educación, 1(81), 83-102. https://doi.org/10.17227/rce.num81-10275

\begin{tabular}{lr}
\hline (c) $\bigodot_{\text {BY }} \$$ & Recibido: 09/07/2019 \\
Evaluado: $29 / 05 / 2020$
\end{tabular}

* Doctora en Educación. Profesora en la Universidad de Caldas, Manizales, Departamento de Estudios Educativos. Correo: josefina.quintero@ucaldas.edu.co

** Magíster en Educación. Docente en la Universidad de Caldas, Manizales, Departamento de Estudios Educativos. Correo: gloria.infante(aucaldas.edu.co

*** Magíster en Administración de la Tecnología Educativa. Docente en la Universidad de Caldas, Manizales. Departamento de Lenguas Extranjeras. Correo: ypaola.valencia@ucaldas.edu.co 


\begin{abstract}
The primary goal of this paper is to examine the classroom environment in Colombian public schools based on the trainee teachers' reflective views when undertaking practicum day-to-day experiences during the final stage of their professional studies. The most important theoretical concepts are based on critical thinking, reflective teaching, and classroom management. The method follows the qualitative research approach, catching a deeper comprehension of the classroom as a complex setting where the teaching-learning processes are carried out according to the curriculum guidelines. Through diaries, observations, narratives, interviews and meaningful strategies, trainee teachers were able to obtain a more in-depth perception to reach a high level of critical reflections in dealing with the most common academic misconduct episodes which perturb a healthy atmosphere inside the classroom. The results are discussed in relation to the most frequent obstacles, the reasons why they emerge and the implications on the school life. Beyond the mechanical task of planning, developing, and evaluating a class, the challenge of helping the most undisciplined students requires a deep process of reflection, critical thinking, and effective solutions in the light of current international theories and national education policies concerning teacher preparation goals.
\end{abstract}

\section{Keywords}

classroom environment; reflective teaching; academic misconduct; teacher education; public schools

\section{Palabras clave}

ambiente del aula; enseñanza reflexiva; problemas académicos; formación de profesores; escuelas públicas

\section{Resumen}

El objetivo principal de este artículo es examinar el ambiente del aula de clase en escuelas públicas colombianas con base en las percepciones, reflexiones y experiencias directas de los educadores en proceso de formación cuando realizan la última etapa de su formación profesional. Los conceptos teóricos más importantes se basan en pensamiento crítico, enseñanza reflexiva y gestión del aula. La metodología sigue el enfoque de la investigación cualitativa, que permite comprender a profundidad el aula como un entorno complejo donde se llevan a cabo los procesos de enseñanza y aprendizaje previstos en el currículo. A través de diarios, observaciones, narrativas y estrategias significativas, los educadores en formación pudieron obtener una percepción más profunda de la realidad del aula con el fin de alcanzar un alto nivel de reflexiones críticas para aplicar estrategias efectivas en la solución de los problemas académicos más comunes que perturban un ambiente pedagógico propicio. Los resultados se discuten en relación con los obstáculos más frecuentes, las razones por las cuales emergen y las implicaciones en la vida escolar. Más allá de la tarea instrumental de planear, desarrollar y evaluar una clase, ayudar a los estudiantes indisciplinados se convierte en un desafío que exige un proceso reflexivo y crítico acompañado de soluciones efectivas a la luz de las teorías internacionales actuales y de las políticas nacionales relacionadas con la

formación de educadores.

\section{Resumo}

O objetivo principal deste artigo foi estudar o ambiente cotidiano da sala de aula em colégios públicos colombianos baseado nas percepções, reflexões e experiências diretas dos docentes em processo de formação, especificamente quando fazem o último ciclo do seu curso profissional. Os conceitos teóricos más importantes baseiam-se no pensamento crítico, no ensino reflexivo e na gestão da sala de aula. A metodologia segue o modelo de pesquisa qualitativa que permite compreender a profundeza a sala de aula como um ambiente complexo, onde são feitos processos de ensino e aprendizagem programados no currículo. Através de diários, observações, narrações e estratégias significativas, os docentes em formação puderam obter uma percepção mais extensa e viva da realidade da sala aula Isto, com o intuito de atingir um alto nível de reflexões críticas para aplicar estratégias efetivas na resolução dos problemas acadêmicos mais comuns que perturbam um ambiente pedagógico favorável. Os resultados são discutidos em relação com os obstáculos mais frequentes, as razões pelas quais emergem e as suas

N. ${ }^{\circ} 81$ implicações na vida colegial. Além da tarefa instrumental de planejar, desenvolver e avaliar uma aula com alunos indisciplinados, o professor encara um desafio que exige um processo reflexivo e crítico acompanhado de soluções efetivas à luz das teorias de circulação internacional e das políticas nacionais relacionadas à formação de professores.

\section{Palavras-chave}

ambiente de sala de aula; ensino reflexivo; problemas académicos; formação de professores; escolas públicas 


\section{Introduction: Preparing Reflective Teachers}

International literature and national legacy are very clear in warning that risks and challenges for the fulfillment of certain essential conditions are necessary in the current twenty-first century. The United Nations Educational, Scientific and Cultural Organization (Unesco, 2014) emphasizes that learning to live together is one of the most important pillars of education throughout life. However, although promoting coexistence, respect, tolerance and shared experiences inside the classrooms are included as an imperative institutional policy, uncertain disruptive behavior demand deeper and proactive solutions on the part of the entire educational community.

According to Hederich-Martínez \& Camargo Uribe (2019), educational learning is referred to "that which is intentional and planned within an institutionalized, hierarchical, and progressive educational model, as the one acknowledged in our contemporary societies" (p. 6). This quotation underlines the curriculum purpose of preparing new educators able to select coherent contents and goals according to the interests and expectations of future schoolchildren generations. Although teacher training programs select and apply modern theories to plan and evaluate learning, the real classrooms exhibit a big gap between the real educational settings and the hierarchical and intentional plans which can be perceived as isolated and far beyond the reach of beginning teachers.

Moreover, concerning new generations of students, Benade (2015) explores the relationship between reflective practice and learning through critical, theoretic and hermeneutic approaches, arguing that "learning and teaching at school must prepare young people for engaging in a complex and dynamic world deeply influenced by globalization and the revolution in digital technology" (p. 42).

Following the guidelines disseminated by Unesco (2014) in Education for all, the international human rights codes and the Political Constitution (1991), new professionals are challenged to develop key skills and competencies such as reflective thinking, lifelong learning, critical thinking and healthy coexistence among people and peoples (Martínez-Scott et al., 2017; Munévar, 2018). Hence, educational institutions are privileged settings of friendship and coexistence where the new generations of citizens ought to be assured the normal satisfaction of fundamental freedoms and human rights (Munévar \& Giraldo, 2015) promoting well-being, social justice, human values, and peaceful resolution of conflicts among students.

On another note, Colombian universities prepare teachers who become the new professionals serving society for the nation type that should be reconstructed. Those who are studying to be teachers develop 
an integral process called teaching practicum during the last stage of the curriculum plan as a graduation requirement. Prospective teachers select an educational institution — whether urban or rural—and immerse there for about one academic year.

It is hard for new teachers to stop being a student and accept a teacher's role serving public or private institutions (Macías \& Sánchez, 2015). When mature students of educational careers undertake practicum experiences, they appreciate the opportunity to engage in authentic classrooms although they feel under-prepared to manage large groups made up of girls and boys with diverse ranges of behaviors, interests, needs and learning styles. Given this, in order to address relevant concerns, they are trained in the art of becoming integral educators exploring effective solutions and accessing scientific literature.

\section{Suitable learning environments}

Suitable learning environments in educational settings embrace effective methodologies, motivation and teacher-students' interaction. It means not only demonstrating the ability to conduct a class and evaluate the assimilation of the target content or the accomplishment of the instructional objectives, but also to investigate the learning conditions, students' attitudes, previous knowledge, opinions about a topic, as well as to generate concerns, ideas and to encourage critical thinking. Positive attitudes adopting reflective and purposeful competencies towards recurrent and uncertain circumstances are required.

Usually, in that transition (from being students to becoming teachers), trainee teachers handle different degrees of tension, encountering situations that go against their greater academic benefits taking into account that classroom management is a determinant factor to do a successful class. In many cases, they become impatient and to some extent reach a degree of hopelessness. About it, Sieberer-Nagler (2016) says:

Classroom climate is the social climate, the emotional and the physical aspect of the classroom. The classroom climate influences student growth and behavior. A positive classroom climate feels safe, respectful, welcoming and supportive of student learning. (p. 166).

The definition given by Sieberer-Nagler (2016) is a point of departure to understand that "Classroom management is intended to provide students with more opportunities to learn all of the things that a teacher does to organize students, space, time, and materials so that students' learning can take place" (p. 163). 
From a theoretical point of view and assuming that learning is an active, creative, rational, emotional, and intentional construction of knowledge, the process of constant review of one's practices should be displayed in the formal education system. Evidently then, teacher preparation programs will increasingly find themselves motivated to qualify their core educational actions, learning, values and beliefs.

Consequently, the following research question was posed: What are the most frequent obstacles affecting classroom atmosphere, and how do trainee teachers face them?

Derived from the above research question, the following objectives were stated:

» To identify obstacles, moments, and circumstances associated with disruptive behavior in school classroom settings.

» To determine how trainee teachers perceive the problems related to disruptive behavior in order to favor a better classroom atmosphere.

» To analyze the most effective strategies carried out by trainee teachers aimed at reducing the most frequent discipline problems that emerge during a class.

\section{Reflective thinking as a way to question existing practices}

In relation to the most evolving literature, the meaning of terms such as reflection, classroom environment and successful class is being reconstituted. Benade (2015), Dewey (1910), Freire (1996), Giroux \& McLaren (1989), and Schön (1987) each argued, in their own way, for reflective and critical thinking as a way to question and change existing practices. They assert that reflective practice promotes self-awareness and that curriculum design and development is not intentionally neutral. Both academic staff and students must be disposed and self-aware to change, breaking with the past or current reality.

At the beginning of the twentieth century, Dewey (1910) stated that individuals are reflective thinkers. Some decades later, Popper (1959) stipulated that science, learning, thought and language are epistemic activities and that human beings are always solving problems. It means that problems and ideas do not germinate in barren or passive brains. Freire (1996) argued that at no stage of learning there has been any mechanic transfusion of knowledge to the student's brain. In contrast, a long continuous period of arduous intellectual activity may ensure an adequate and fruitful work. 
As education is not neutral (Freire, 1996), thoughts and actions are to be conscious and ethical. It means that ideas and thoughts sprout in active minds enriched by varied experiences of individuals who are predisposed and engaged to such activity. Taking into account that knowledge is constructed by curious and creative minds, classroom problems are neither discovered nor solved by passive minds. Reflective thought is not a step-by-step process that one can master by following rigid directions as in an operative manual or rigid guideline.

Critical thinkers keep asking and exploring questions: Is it true? Is there a better explanation for this phenomenon? What is the best solution? These inquiries mean that teachers are able to both self-reflect and critically refuse the statu quo, rigid routines and conformity. Critical attitude and insatiable curiosity about the surrounding world, which is multilayered and complex, should be adopted. For this reason, educational processes must be liberated from cultural prejudices, generalizations, myths and assumptions that obscure the way of thinking (Benade, 2015; Freire, 1996; Giroux and McLaren, 1989).

In the field of education, successful reflective teachers (like a scientist) may appear to solve problems magically; nonetheless, high levels of inquiry are necessary. Fruitful ideas flow from their alert mind when they are trying to put disturbed or puzzles thoughts into some meaningful order. In the critical-oriented world of today, universities are invited to train a new generation of teachers concerned with the processes of inquiry. Reflective, critical and autonomous teachers will be able to recognize difficulties picturing a representational model of the world which guides their behaviors and actions. They are to be engaged in a process of observation, interpretation, and reflection as a previous phase to solve immediate classroom difficulties.

\section{Materials and Method}

The research process assumed the epistemic characteristics of the qualitative-interpretivist paradigm (Creswell, 1998; Elliott, 1991). That is why each trainee teacher's class was observed during a six-month academic period. Besides, this paper makes part of a narrative research project about critical pedagogy from Universidad de Caldas in Manizales, Colombia, whose purpose was to understand curriculum reforms in undergraduate education programs. Five elementary public schools located in the Colombian Coffee Region, where future teachers develop their teaching practicum, were approached to participate in the field work. These institutions have begun to adopt a reflective and critical orientation included in the curriculum model. 
The group of participants was integrated by five novice trainees (three women and two boys), from 22 to 25 years old who were qualifying themselves to become teachers in elementary, secondary or middle state institutions, guided by experienced practicum advisors. They are finishing the last academic stage, which is a requirement for graduation as educators. Those public school classrooms present disruptive behavior episodes that, if not properly managed, become barriers blocking down the access to contents, expectations and feelings related to the everyday academic life. For this reason, all of the participants had to develop inquiring, reflective and critical competences.

Each novice trainee teacher was in charge of one course with an average of 40 students, ages ranging from ten to twelve years, being in total 200 classmates approximately. Likewise, eight diaries were reviewed, five from novice teachers and three from practicum advisors. Narrative texts containing indiscipline episodes, interaction difficulties and the most exasperating occurrences during a period of class, followed by the trainee teachers' practical solutions, were systematically registered in the personalized diaries.

Zulfikar \& Rahman (2018) consider that "most in-service teachers regard reflective journals as an effective tool to increase teaching awareness, and thus improve their performance during teaching" (p. 1). Therefore, to enhance the credibility of this project and to allow the triangulation process, data was also collected, recorded and transcribed from semi-structured interviews, and a small focus group of long-experienced teachers, including the principal and the practicum advisors' comments. Interviewees were engaged in discussions and practical strategies; they were asked a range of questions related to the trainee teachers' narratives.

\section{Results}

After a careful process of data analysis three thematic categories emerged, which were used in reporting the results: 1) Obstacles and unpredictable circumstances; 2) Favoring a better classroom atmosphere; 3) The desire to be effective teachers.

\section{Identifying obstacles and unpredictable circumstances}

The following most frequent registers taken from the diaries which were contrasted with excerpts from the interviews show that it is not difficult for prospective teachers to prepare a class despite their lack of expertise. In fact, they enjoy creating didactic materials, designing games, looking for creative and enjoyable activities, and maintaining a noticeable interest in 
describing difficulties as they occur in the classroom. This is the case of indiscipline and disruptive behavior which constitute an emerging point of reflection that merits immediate solution.

The first trainee teacher (a young woman) reported in her diary:

Whenever I arrive to the classroom, students are never ready to start the lesson. Boys do not like to stay in their respective seats, and they also seem to get bored since the beginning of the class. According to my lesson plan, I started organizing the room, listening to a song and showing them creative materials. I must develop a methodological process in accordance with the students' interests. They understood what I wanted to explain despite the bad acoustics of the room and the little free space to walk because there are 45 people gathered in a small classroom. Even, when I told them to work in small groups, play a game and perform interesting activities to reinforce the lesson, they usually did not stop talking. I got tired too and the class did not finish according to the lesson plan.

During the interview, she added the following difficulties:

» This room is not appropriate to develop a successful class.

» Sometimes they forget the instructions and ignore the purposes of the feedback.

» They do not understand the explanations. I have to repeat the topic several times.

In the above narratives, the trainee teacher highlighted some value to the initial and final moments of her class. She imagined that all students should be quiet, seated on their respective chairs waiting for the new lesson. Nonetheless, from this moment on, she noticed a discrepancy between the real atmosphere and the sequence of her lesson plan, which had been designed according to the principles of a successful class: songs, games, creative materials, a step by step process, individual and small groups, instructions and feedback. She became disappointed because her "well-prepared plan" was not enough to avoid neither indiscipline nor students' lack of respect attitudes such as shouting, kicking each other, insulting, and swearing, among others.

The second trainee teacher (a young woman) believed that carrying out a successful class is an arduous and impossible task. She reflects upon the need to be able to adjust herself to her students' attitudes. She wrote down:

Well-prepared classes are not enough to catch the students' attention; although I prepare sufficient didactic materials and good lesson plans, very difficult episodes that I cannot control emerge. I noticed that some students start the mess when they finish their tasks. Moreover, I know that I must strive to be patient 
Later on, she elaborated on these episodes during the interview:

» Students shout, beat, kick each other, insult, say ugly words, and so on.

» They push themselves at the playful activities.

She felt confronted by change, especially in relation to "horrible classes". She was willing to adjust her ideas about children's disruptive behavior having students to be productive and successful, recognizing this as a vital shift in her way of thinking.

I've also had horrible classes. There were no appropriate conditions for a good class. Truthfully, I do not know how to provide that good atmosphere I've always wanted. I am distressed just knowing that I am going to that room.

The third pre-service teacher (a young woman) also referred to establishing order and catching learners' attention as the most stressful action in dealing with classroom atmosphere. Stopping a class means losing control over one's own pedagogical action. However, she recognized she was willing and committed to change. This was the entry in her diary:

This class was a huge problem for me. I am required to establish order. I had to stop the class for several minutes because the teenagers could not focus their attention. They were talking too much, and did not finish the exercise. I'm nervous and need improvement.

The fourth teacher trainee (a young man) used the diary to be reflective, including feelings, emotions, curiosity, and memories, which allowed him to gain awareness of his own pedagogical processes. We can infer from the diary entry, that he was worried and confused. Surprising episodes, such as one student slapping other, uncomfortable settings, and unexpected episodes diminished his positive attitude. However, he finally identified important insights to improve his teaching experience upon which he could reflect on later.

There are always surprising events that I have not foreseen. For example, in the middle of the class a student slaps another. It's a shock. Here I change the script. Even an experienced and mature teacher would be astonished with this. I bear in mind that when dealing with large groups something unexpected will always happen, but what is really going to happen?

The narrative above was compared with samples of answers taken from the interview, confirming again that good didactic materials and ludic activities did not work to keep a pleasant classroom atmosphere.

I remember a distressed episode. Before each class, I always prepare interactive material to work in small groups. One day, I gave each group a theme to make a billboard. From each group they called me to explain 
again and again. Before ending the class, the students were ready to leave out; they did not want to present the tasks because they feel ashamed to speak in public. Honestly, discipline was a disaster.

The fifth teacher trainee (a young man) reported the following episode in the interview:

It was the last hour of the day. I felt disappointed because I asked the students to accomplish the tasks in groups, but it did not work. They were shouting at their peers and did not start the assignment. I think it is very difficult to teach in a large group because each one has not the opportunity to participate.

After observing the class, the advisor wrote suggestions in her diary encouraging him to write and share better reflections, which supports his view that he, as a beginner, should seek feedback, but he wants to use their reflections as evidence in their appraisals.

I perceived moments of tension. The teacher trainee was located in a classroom, which provided an unfavorable environment due to its size, in relation to the number of students, even if there were varied resources such as video beam, books, flash cards, etc.; it was hot, and it had not enough illumination. There was an obvious effort to maintain discipline, through interactions and by channeling some resources, technology and materials. Children were restless because of the overcrowding that prevented them from having freedom of movement, and that led them to invade spaces with the usual reactions that affected the order of the class: Perturbing noise because children spoke at a very high volume, they whistle, etc. Nonetheless, the teacher trainee maintained an attitude of calm and patient.

The second paragraph of the advisor's entry emphasizes on the use of time, restlessness, anxiety, eagerness to finish the class, and other aggressive behaviors.

The teacher trainee wasted much time on writing on the board. Children seemed very restless and anxious, considering the circumstance of time (it is twelve o'clock); they were bored, and they wanted to go home already. They took advantage while the teacher was writing on the board, and began to throw her little paper balls. They stood up; they abandoned their chairs, fought, etc. The class became a complete chaos.

The following additional difficulties were extracted from a long list of concerns, collected during the lessons, which were written down by the trainee teachers in their diaries and triangulated with interviews, as well as with the advisors' comments: 
» There are dirty folders, unsolved handouts.

» Low grades because of the frequent disorder, lack of attention, external and internal distractors, interruptions, and insufficient time to finish the exercises.

» Rudeness, shouting, rebellion, yawning, sabotage, chatting while explaining the lesson.

» A great number of students do not answer the questions; they pose isolated questions from the subject.

»It is necessary to go around the same topic, explaining again and again.

» It is difficult to handle talkative students and children complaints.

» Students kick, mock, hit the desk, look with anger, and laugh when others speak.

» Students frequently insult their partners, shake shoulders, assault physically.

» Students snatch classmate objects such as pencils, notebooks, colors, and other belongings.

During an interview, with a trembling and anguished voice, the trainee teacher verbally corroborated her written reflections by answering the following question: What are the most difficult problems affecting your classroom atmosphere, and how do you face them?

» I think it is difficult to teach young people today.

» I get many complaints and I never know what to say.

» I recognize that I am not prepared to respond immediately to students' behavior because of the classroom atmosphere, my impatience and temper.

» Although it is said that students like to learn by playing, games, on the other hand, generated more indiscipline in my class.

» This is difficult for me. How do I make them shut up? What do I tell them, and what activities can I think of?

» I have tried to be more confident and I have not succeeded.

Furthermore, participants also reported some common problems in public schools. They complained about very cold rooms in the basement or the unbearable heat of the last floor, the sweat of those who run in or out the room, unpainted walls, smelly bathrooms, full garbage cans, among other factors that did not help at all healthy coexistence in the classroom. Likewise, collaborative work is difficult to manage in large groups distributed in narrow rooms, so that some students would rather not do it. While some of them do not always prefer to work with their classmates, others decide to study by themselves. Thus, it is difficult to finish a task under certain adverse conditions covering times, goals, and topics. 


\section{Favoring a better classroom atmosphere}

By sharing the problems and presenting progressive balances of the practicum processes, it is possible to reveal how the climate inside pedagogical settings is understood, confronted and improved through immediate and practical strategies on the part of trainee teachers. The desire to create a pleasant classroom environment is evident, so it is necessary to focus in it.

In this finishing stage of their professional studies, pre-service teachers were expected to be autonomous, responsible and ready to create and keep a pleasant atmosphere during the lessons. They were able to figure out different strategies. The advisors considered that writing narratives in the diaries and sharing them with their classmates could be an essential feature of reflective teaching. At the end of the teaching practicum, and after a persistent period of trial and error initiatives, corrective measures suggested by the advisors with the aim of improving the most prevalent situations were:

» Reinforcing self-confidence and students' interaction

» Evaluating and fostering permanent self-assessment

» Reflecting on the most frequent students' difficulties

» Being face to face with the group, mobility, eye-contact

» Looking for management of individual counseling

» Leading the students to learn from their own mistakes

» Bearing in mind a non-punitive intention

»Designing new ways, leading to the most undisciplined students' progress

» Establishing mutual commitments

» Underlying the importance of healthy coexistence as a factor for successful learning

» Being always respectful with the group demonstrating self-confidence and addressing each other in a friendly way

» Challenging students to do better by participating in activities, asking and answering important questions.

As a result, through deeper reflections it was found that a variety of topics were registered on the journals, which were structured into long lists of changes and improvements made up during and after each new lesson. Trainee teachers, playing the role of beginning problem solvers, articulated assertive reflections as an endless activity about class disruptors' progress.

The foregoing perceptions could be substantiated by the participants during the interviews:

» It is very important to describe effective strategies for dealing with out-of-control schoolchildren using the diary 
» Reflection as beginners with classmates working together is also essential

» I increased my level of awareness and motivation writing on the day just ended, and thinking about what needs to change for classroom disruptors going forward

The commitment and responsibility of trainee teachers to carry out their work is evident. In that same spirit, they have found that it is indispensable to take advantage of the apparent good relationships that have been established. This seems to indicate that a mature and respectful attitude has been highly helpful in resolving difficulties that normally occur in schools, particularly at the level of interpersonal relationships.

The practicum advisor highlighted the trainee teachers' progress concerning responsibility, equal treatment, participation, and other management strategies:

The teacher trainee well leads the class; she knows how to give students a friendly and equal treatment favoring opportunities to participate and express their ideas. She approves and encourages good interventions.

The teacher trainee knows how to choose the examples for clearly illustrate the themes; she makes an adequate distribution of time; she is very tender with children but, at the same time, she demands them a good performance; so, she provides a pleasant learning environment.

In consonance with the detailed data analysis, at the end of the teaching practicum stage, prospective teachers were competent to delimit spaces, demarcate territories to catch student's attention, characterize the difference among the front rows, back rows, left, right, bottom corner, and adjacent places to the board. Additionally, they identify those areas where participants move the most and those where they never go to. Each of these affects learning in different ways.

\section{The desire to be effective teachers}

It should be noted that the advisors confirmed their advisee's desire to be effective teachers. Day after day, teacher trainees looked for the best tools to control the indiscipline, creating a collaborative, respectful, and joyful atmosphere. It was important to reinforce rules, to provide engaging tasks that were not too difficult nor too basic, to develop varied technical teaching skills, and so on.

Likewise, in the final stage of their professional studies, trainee teachers went deeper seeking to understand their experiences. As active thinkers, they were expected to conduct their own professional learning and autonomy being more knowledgeable, responsible, respectful, and 
effective in their work. They were able to design creative and playful materials, develop fun activities, encourage participation, carry out innovative methodologies, formulate clear achievements, being punctual and sharing a positive attitude towards significant teaching endeavors. Yet, students' indiscipline and disruptive behavior are unavoidable and become the biggest obstacle to ensure a pleasant learning atmosphere, even for older teachers.

The following samples, extracted from the advisors' diaries, highlight that for controlling a group, the trainee teachers became coherent in front of the class, using didactic material that really works, trying to keep harmony and a good atmosphere:

At the end of the practicum stage, it means when the academic period was next to finishing, the teacher-trainees did a big effort for counteracting the students' indiscipline. They were able to use strategies to get to know them, their attitudes and their capabilities when carrying out individual and group activities. On the other hand, young teachers understood that it was not appropriate, therefore, to be extremely rigid; i.e., scolding, threatening, raising the voice, making the students feel thoughtless, etc.

In an interview, the teacher trainees stated:

» I use resources as pictures, real material, colors, maps, games, and figures to catch the attention of negligent children

» I do the best trying to encourage them to feel good at school

» It is recommended to avoid excess of adulation and over-stimulation

In this line of work, reasonable expressions were registered in the final pages of the pre-service teachers' diaries, as well as during the interviews and in the practicum advisors' comments, emphasizing the desire to be successful teachers, and how an increasing number of schoolchildren appreciated each class. "I really enjoyed the attitude of this group today" is an illustrative answer corroborating a high level of satisfaction according to the expected results.

As mentioned earlier, trainee teachers were very pleased with the way in which they controlled the last lessons. They also recognized that the most difficult of this profession is, of course, changing the students' attitude towards the desire to learn and letting them be autonomous and enthusiastic.

» Time is over. I have finished the last class. They showed their satisfaction with applauses

» I've done better classes. Today I feel happier than yesterday

" Now, I observe with different eyes

» I heard words of gratitude and congratulations from several students. I have one word to remember: thank you 


\section{Discussion}

National and international researchers identify classroom settings as one of the most commonly discussed issues concerning teacher preparation programs (Fandiño, 2013; Macías \& Sánchez, 2015). In particular, following the principles of contemporary educational authors (Creswell, 1998; Elliott, 1991), classrooms become natural, favorably-conditioned places of interaction and reflection (Schön, 1987) for both teachers and learners.

Current literature deals with different variables concerning academic goals, such as motivation and regulation, students' behavior and attitudes, learning environment, classroom physical conditions, pleasant coexistence, teaching methods, curriculum contents, academic goals, student's learning styles, autonomy, cultural background, and so on.

Hederich-Martínez \& Camargo Uribe (2019), after critically reviewing international studies, identified "those characteristics that are less favorable to the school learning situation" (p. 9). One important issue shows that some students with higher scores in certain types of learning also display low performances in others. There are students exhibiting disorganized and confusing methods of study. Low academic goals have to do with lack of regulation, motivation, and cooperative learning. Superficial information processing strategies are also associated with low-quality learning and seriously affect academic life. Students do not know very well either how to develop their academic tasks, nor the amount of material to be assimilated.

Due to ineffective approaches to accomplish learning tasks, some students also exhibit greater difficulties to reach academic goals. When facing classroom atmosphere, both new and experienced educators must have the courage to change their own beliefs or convictions. For example, the issue that conducting a successful class is an impossible goal, in this case, to be able to change the students' attitudes, lack of discipline to get a pleasant coexistence. A better alternative, on the other hand, is to assume a reflexive, comprehensive and purposeful attitude to face frequent, real and uncertain situations which deserve a deeper comprehension on the part of the academic community. "Questionable too, is whether sustained pedagogical changes to practice will arise from simply making notes over one's planning, as suggested by several teachers" (Benade, 2015, p. 48).

Hederich-Martínez \& Camargo Uribe also ask the following question: "What is the ideal student of the educational system?" (p. 18). The authors' answer is:

[...] they build their own knowledge, which is determined by their own personal interests, and does so in a completely self-regulated manner: the students themselves manage and assess their process, in relative independence from external information. More than this, this ideal 
student can work independently on content and learning activities and does not need any kind of stimulation from their teachers. (p. 19).

Although in their 2019 study the quoted authors were focused on higher education contexts, this portrayal is directly linked to the classroom environment in the basic levels. Maybe the real situations in the elementary and secondary pedagogical settings directly influence the ideal student profile that will be required by the university, later on.

"In light of the view that twenty-first century learning requires teachers to make significant shifts to their practice and their thinking about the purposes of education" (Benade, 2015, p. 47), it is essential to know how new generations of teachers and students define and construct relationships of coexistence, respect, peace and public safety in the school (Gregory et al., 2016). Nonetheless, reflective teaching practicum is not a matter of recipes, rigid formulas, and mechanical plan design or course tracking. Notable theorists (Dewey, 2021; Freire, 1996; Giroux and McLaren, 1989) warned that both beginners and experienced teachers require a big dose of willingness to carefully see and understand the visible and invisible situations that emerge from everyday actions, considering that classrooms demand a persistent and challenging activity.

So far, assuming the principles of a reflective-critical hermeneutic approach, as Benade (2015) has pointed out, narratives go beyond exasperating episode descriptions. A reflective trainee teacher will not only be able to make sense of his or her educational profile, but also to engage with the experiences of the classroom disrupters and seek feedback from other colleagues and experts. In addition to reflecting on trainee teachers' performance, critical narratives would serve the ends of educational institutions with the desire to be autonomous, collaborative and focused on sharing expectations. This line of action agrees with Freire's (1996), Schön's (1987), and Giroux and McLaren's (1989) conceptions of an ethical, autonomous and reflective professional as one who could interact with others in the search of learning, acquiring higher levels of critical awareness.

For classroom management it is quite important to create successful environments where reflective and critical teachers play a fundamental role, as well as communication skills in terms of being proficient for contributing to establish and maintain discipline and learning routines. According to Muna (2019), time-consuming problems that demand solutions are indiscipline, disruptive behavior and lack of expertise, which constitute an important point of reflection. Besides, echoing Zulfikar \& Rahman (2018), "reflective journal facilitates teachers to reflect on their teaching and then generate feedback for the improvement of their classroom practices" (p. 1). In the following paragraph, Sieberer-Nagler (2016) presents a more explicit description concerning classroom management: 
Everything a teacher does has implications for classroom management, including creating the setting, decorating the room, arranging the chairs, speaking to children and handling their responses, putting routines in place (and then executing, modifying, and reinstituting them), developing rules, and communicating those rules to the students. These are all aspects of classroom management. (p. 163).

From the above points of view, teacher education programs should include an awareness-raising component that helps to expand the prospective teachers' experiential knowledge. This is possible and necessary because teacher trainees assume the challenge to face and promote a healthy classroom atmosphere.

It can be stated that problems related to classroom environment are also grounded in the institutional norms. The exhaustive application of regulations and the rooted practice of making notes on the notebooks or inviting the parents to observe their children misbehavior are not always the best solutions. "Students' work is much better in environments that are well-defined in terms of dos and don'ts and when they exactly know the rights and wrongs. It is not so good when rules are ambiguous and inconsistent" (Sieberer-Nagler, 2016, p. 165).

Providing effective pedagogical responses to solve those greater difficulties is a prime decision-making measure within the educational settings. Elementary and secondary institutions ought to do the required changes in the interests of youth who have to live together in the current century sharing educational discourses and practices.

To this extent, what is the backbone of what goes on around the ideal atmosphere to favor the teaching, learning and training processes? It is necessary to dive into the meaning of the classroom as a natural environment suitable to coexistence. Derived from the National Political Chart (Constitución política, 1991) as well as from the Unesco (2014), four main pillars should be directly or indirectly related to human rights: equity, treatment of conflicts, coexistence and peace, meeting the needs of global proposals. Thus, promoting education in consonance with the current twenty-first century goals is the most challenged promise which has to be based on the co-responsibility of the State policies, and has been extensively documented in previous research works (Collins, 2017; Munévar, 2018).

\section{Conclusions}

The most frequent obstacles, moments and circumstances associated with disruptive behavior affecting classroom environment inside public schools, and how trainee teachers faced them were the core content of 
this research work. In accordance with the stated objectives, and after a careful data processing, the conclusions drawn below emerged from three thematic categories: 1) exasperating disruptive behavior, obstacles and unpredictable circumstances; 2) strategies that favored a better classroom atmosphere; 3 ) the desire to be effective teachers.

When calling the role as teachers and being immersed into real school settings, prospective teachers start having very good relationships with students, accepting that schoolchildren's behavior affects the classroom atmosphere. It is important to discern how inexperienced pre-service teachers faced and favored classroom environment to better conduct pedagogical processes according to educational goals. Nevertheless, they perceive that the lack of discipline and the disorder due to overcrowded rooms are already nominated as common unsolved problems. Perturbing situations seem to be an uncertain difficulty because they cannot be solved straight away. Consequently, trainee teachers face a continuous tension between wanting to conduct successful lessons and exhibiting endless efforts aimed at counteracting disruptive students' behaviors.

Although educators in progress show a great deal of anxiety, it is evident their sensitivity to generate learning environments and to discover hidden factors in their daily practices that affect learning and training processes. In a later stage in the education curriculum programs there are great challenges, especially by those who have understood the value of reflecting on and writing down the experience carried out in real contexts of learning, teaching, and training processes.

The most effective strategies that pre-service teachers explored to reduce the most frequent academic misconduct episodes that emerged during their classes were analyzed. Writing reflections through diaries contrasted with interviews provided effective opportunities to develop a deeper understanding of the way in which teacher trainees operated in their classroom, explaining how and why certain changes favor a better classroom atmosphere.

Persistently, both trainee teachers and advisors risked inventing and testing different ways to modify routines and unwanted behaviors. As in a game, the classroom should be an expectant scenario because of the movements, choreography, actors, interactions, characters, scenes, outcomes, and persuasion of a public with different expectations, interests and necessities. Above all, they identify strengths and weaknesses as well as useful strategies in terms of improving academic goals. In this way, new teachers are able to provide ideas to address all situations affecting their school environments.

It might be worthwhile to point out that such purpose was possible through progressive levels of reflection, critical attitude and the desire to overcome difficult real situations having good results and indicators of success, which are linked to the institutional goals. 
Indiscipline, disruptive behavior, coexistence, and general instructional work as factors that directly affect the classroom atmosphere become a thematic focus to reflect on and transform, which implies to turn the classroom and the school into searchable scenarios. Using real data that emerge from educational contexts, reflective trainee teachers are able to explore direct immediate strategies that help them recognize themselves as future educators and to qualify their performance. Given this, there are constant concerns to ensure comfortable environments to develop successful classes.

In that sense, at the end of their teaching practicum, trainees of educational careers feel more competent and more self-assured to observe and to take corrective measures, demonstrating more in-depth analysis, authority, and professionalism.

\section{References}

Benade, L. (2015). Teachers' critical reflective practice in the context of twenty-first century learning. Open Review of Educational Research, 2(1), 42-54. 10.1080/23265507.2014.998159

Collins, P. (2017). The value of respect: what does it mean for an Army? Journal of Military Ethics, 16(1), 1-18. 10.1080/15027570.2017.1337712. http://www.tandfonline.com/toc/smil20/current

Colombia. (1991). Constitución política [Political Chart]. http://www.cna. gov.co/ cont/documentos/legislacion/constitucion.pdf

Creswell, J. W. (1998). Qualitative inquiry and research design. Sage.

Dewey, J. (1910). How we think. Heath and Company. https://doi. org/10.1037/10903-000

Elliott, J. (1991). Classroom action research. Cambridge Institute of Education.

Fandiño, Y. (2013). Knowledge base and EFL teacher education programs: A Colombian perspective. Íkala, Revista de Lenguaje y Cultura, 18(1), 83-95.

Freire, P. (1996). Pedagogia da Autonomia: Saberes Necessários à Prática Educativa. 25 Edição. Editora Paz e Terra.

Giroux, H. \& McLaren, P. (eds.). (1989). Critical pedagogy, the State, and the struggle for culture. suny Press.

Gregory, A., Clawson, K., Davis, A. y Gerewitz, G. (2016). The promise of restorative practices to transform teacher-student relationships and achieve equity in school discipline. Journal of Educational and Psychological Consultation, 324-353. 10.1080/10474412.2014.929950

Hederich-Martínez, C. \& Camargo Uribe, A. (2019). Critical Review of J. Vermunt's Learning Pattern Model. Revista Colombiana de Educación, 77, 1-25. https://doi.org/10.17227/rce.num77-9469. 
Macías, D. F. \& Sánchez, J. A. (2015). Classroom management: A persistent challenge for pre-service foreign language teachers. Profile: Issues in Teachers' Professional Development, 17(2), 81-99. https://revistas. unal.edu.co/index.php/profile/article/view/43641/51396

Martínez-Scott, S., Monjas-Aguado, R., \& Torrego-Egido, L. (2017). Hunger and prejudice. A study of development education in teachers' training. Proccedia Social and Behavioral Sciences, 237, 950-955. https://www. sciencedirect.com/science/article/pii/S1877042817301349

Muna, F. (2019). Effects of Classroom Disruptive Behaviour in Brunei Darussalam. Asian Journal of Research in Education and Social Sciences, 1(2), 10-20. http://myjms.moe.gov.my/index.php/ajress/article/view/7585

Munévar, C. A. (2018). Conflictos en contextos socioambientales en la ecoregión eje cafetero. Cuatro casos paradigmáticos. En C. A. Dávila, C. A. y C. A. Munévar (Eds.). De los conflictos socioambientales a las resistencias territoriales. Universidad Pedagógica Nacional; Fundación Centro Internacional de Educación y Desarrollo Humano Cinde; Universidad de Manizales, 25-68.

Munévar, C. A., \& Giraldo, R. (2015). Desarrollo y derechos humanos: incidencias, aproximaciones y tendencias. Revista Jurídicas, 12(1), 25-42.

Popper, K. R. (1959). The logic of scientific discovery. Basic Books.

Schön, D. (1987). Educating the reflective practitioner: Toward a new design for teaching and learning in the professions. Jossey-Bass Publishers.

Sieberer-Nagler, K. (2016). Effective classroom-management \& positive teaching. English Language Teaching. 9(1). http://dx.doi.org/10.5539/ elt.v9n1p163

United Nations Educational, Scientific and Cultural Organization-Unesco (2014). LatinAmerican and the Caribbean. EducationforAll2015. Regional Review. http://unesdoc.unesco.org/images/0023/002327/232701e.pdf

Zulfikar, T., \& Rahman, M. (2018). Understanding own teaching: becoming reflective teachers through reflective journals, Reflective Practice, 19(1), $1-13,10.1080 / 14623943.2017 .1295933$ 